\title{
Disciplinary cases at high schools: An analysis of decisions of disciplinary committees
}

\author{
Uğur Çetinkaya ${ }^{1}$ and Mehmet Koçyiğit ${ }^{2}$ \\ ${ }^{1}$ Ministry of National Education, Yaşarlar Zekiye Ana Secondary School, Turkey (ORCID: 0000-0002-6804-3272) \\ ${ }^{2}$ Afyon Kocatepe University, Faculty of Education, Turkey (ORCID: 0000-0002-1836-844X)
}

\begin{abstract}
The aim of this study is to examine the records of secondary education institutions' disciplinary committee decisions, and to put forth the reasons why high school students are punished, and which punishments are given. The distribution of these punishments in terms of students' grade, school type and gender is also explored in the study. In this qualitative case study, the data were collected through document analysis. The study group of the study consists of nine high schools located in a district of a province in the Aegean region of Turkey. The data in the study consist of 384 disciplinary cases recorded in the disciplinary board minute books and e-school between 2016-2020 years. Content analysis was performed on the data. In the 384 disciplinary cases registered in schools, the most frequent punishment is condemnation. The disciplinary punishments are mostly concentrated on male students by gender, in 9th grade students by grade level, and in vocational and technical high school types by school type.
\end{abstract}

Keywords: Education management; Secondary education; High school students; Disciplinary penalties; School discipline

Article History: Submitted 2 August 2020; Revised 29 October 2020; Published online 20 November 2020

\section{Introduction}

Humans are creatures who cannot live alone, but in communities, and also have free will. Therefore rules are needed to ensure that the order of the community in which we live is not disturbed and that people can use their free will in a way that does not disturb the order of the society. As well as the effect of the rules in maintaining the development of the individual in harmony, the rules also play a major role in the fulfillment of the requirements of the education and instruction activities and in ensuring the social order. These rules can be written or unwritten. In this respect, discipline rules are also seen as an element in ensuring compliance with the normal order (Ada \& Çetin-Ölçüm, 2002).

\subsection{The Concept of Discipline}

Different meanings have been attributed to the concept of discipline. The concept of discipline derived from the Latin word "disciplina". Turkish Language Association (2005) defined the concept of discipline as "A community's strict compliance with the laws and the written or

Address of Corresponding Author

Mehmet Koçyiğit, PhD., Afyon Kocatepe University, Faculty of Education, Ahmet Necdet Sezer Campus, 03200, Afyonkarahisar, Turkey.

$\longrightarrow$ mkocyigit@aku.edu.tr

How to cite: Çetinkaya, U., \& Koçyiğit, M. (2020). Disciplinary cases at high schools: An analysis of decisions of disciplinary committees. Journal of Pedagogical Research, 4(3), 312-326. 
unwritten rules of the order; strict order; order; and bond of order". Oxford Learner's Dictionary (n.d.) defines discipline as "the practice of training people to obey rules and orders and punishing them if they do not; the controlled behaviour or situation that is the result of this training". According to Regulation on Secondary Education Institutions of the Ministry of National Education (MoNE, 2013), discipline refers to a set of rules that students must follow. Discipline is defined as the ability to act and comply with rules, laws and principles (Yiğit, 2006). Amoah et al. (2015) defines discipline as readiness or ability to respect authority and observe conventional or established laws of the society or any other organization. According to Buchtova et al. (2015) discipline can be seen as related to obedience, or as a set of rules of behaviour, or as a set of habits acquired through education. Çelik (2006) defined the concept of discipline as the behavior of following formal and informal rules in order to maintain positive living standards. In brief, discipline can be defined as the capacity of obeying the written or unwritten rules of the order in a community and the ability to act and comply with rules, laws and principles in general.

The concept of discipline is often perceived with a negative meaning and it is related to the concepts such as beating, violence and so on (Kaçar, 2018). In fact, the concept of discipline is not exactly a concept with negative meanings, and it has no direct relation with beating or violence (Koçyiğit, 2019). Discipline expresses the ability to comply with the rules and provisions in order to ensure order (Saritaş, 2005). In another aspect, it connotes the ability of the individual to adapt to himself and his environment and also to have respect to self and others (Köktaş, 2003; Ngwokabuenui, 2015). In contrast to the negative image that the word awakens in the minds, discipline includes the principles and rules where individual rights and freedoms are not limited, and responsibilities are shared (Cüceloğlu, 2016). All of the activities that will allow for controlling the behaviors to ensure order in daily life, set regulations and reach some purposes (İlgar, 2000), can be expressed with the concept of discipline. It can be said that adapting to environment, respecting the rights and freedoms of others and sharing social responsibility as well as following the rules can be attributed to the concept of discipline.

Based on the definitions, it can be suggested that the purpose of discipline is not to compel individuals to obey without questioning, but to help them control themselves, develop the relationship of love and trust between individuals, lay the foundation of self-worth and develop the duty of being a model by understanding others (Karataş, 2008; Yavuzer, 2016). As a result, discipline is the determination and implementation of rules that will enable individuals to respect each other's rights and freedoms. Discipline means more than the rules to be followed. It can be considered as a way of life.

\subsection{Discipline in Education}

Discipline in education is a set of precautions and rules that will enable students to behave in accordance with rules and regulations in order to create desired behaviors (Ada \& Çetin-Ölçüm, 2002). It involves display and instruction of the desired behaviors to students, monitoring students' behaviors, rewarding them when they behave well and making them conscious of the misbehaviors if the result is negative (Başaran \& Çınkır, 2013).

The significance of discipline in education stems from different aspects. The first is to provide an effective classroom discipline, and to ensure that students are responsible (Akpınar \& Özdaş, 2013a; Lewis, 2001) thus making classroom management easier and teaching-learning process more effective. Secondly, there are studies in the literature linking school discipline with academic performance (Baumann \& Krskova, 2016), offending (Mowen, Brent \& Boman IV, 2020) and inequalities (Camacho \& Krezmien, 2020). Considering the purpose of the discipline applied in schools, it can be expressed in the form of developing auto-control and responsibility awareness by comparing between their own behaviors and desired behaviors, improving students' self-esteem and socialization, keeping students focused on learning, teaching respect for the rights of others, and developing moral values (Saritaş, 2005). As a result, the concept of discipline is important in in education for providing an effective education, raising socially healthy individuals, serving the 
goals of teachers and students for being in the school, and creating a positive atmosphere in the school. For this reason, researchers interested in education have also focused on discipline and have introduced some discipline models that can help education managers and teachers in preventing undesired behaviors.

\subsection{Discipline Models in Education}

Behavior is the physical or mental movements that the individual reveals in a right or wrong, good or bad direction. Misbehavior is the conscious behavior that is not appropriate for the surrounding. In this context, any kind of disturbing and confusing behavior that prevents educational activities or the realization of the school's purpose, disrupts the positive environment in the classroom, damages the classroom management, classmates or belongings can be expressed as misbehavior (Ercan, 2007, Erdem, 2019).

When related studies are examined, different discipline models as guides for teachers to prevent or to handle misbehaviors can be pointed out. Although they will not be discussed in detail in this study, it is necessary to mention their names here when it comes to discipline in education. The literature includes the discipline models such as Canter Model, Glasser Model, Kounin Model, Behavioral Model, Gordon Model, Dreikurs Model, Ginott Model, Responsibility Based Class Management Model and Interpersonal Relations Analysis Model (Babaoğlan, 2014; Celep, 2008; Cemaloğlu \& Kayabaşı, 2007; Çelik, 2006; Durukan \& Öztürk, 2005; Erdem, 2015; Kıran, 2005; Sadık, 2006; Sarıtaş, 2005; Tertemiz, 2007; Tofur \& Altıntaş, 2019; Uğurlu, 2016), each focusing on a different aspect (i.e. ripple effect, interaction with students, non-verbal behaviors of teachers, rewards and punishments etc.) to provide discipline and facilitate classroom management. These models are given place in course books and taught to prospective teachers in courses such as classroom management in education faculties in Turkey.

\subsection{Discipline in Secondary Education Institutions}

Disciplinary practices applied in high schools in our country are evaluated according to the principles of the Ministry of National Education Secondary Education Institutions Regulation, which was first published with the regulation in the official gazette numbered 28758 on 07.09.2013 and then updated with the regulation in the official newspaper numbered 31121 on 08.05.2020. The tenth part of the Regulation includes Provisions Regarding Student Behaviors, and Rewards and Discipline. In these sections, the rules to be followed by the students and the behaviors expected from the students, the protection of the students, the rewarding of the students, the disciplinary punishments, the behaviors and actions that require disciplinary punishment, and the principles of implementation are included. In high schools, students are expected to receive punishments such as condemnation, short-term suspension from school, change of school, and exclusion from formal education due to their defective or punitive behavior. While the behaviors expected from the students are explained in Article 157 of the regulation, issues such as behaviors requiring disciplinary punishments, what to do in case of repetition and principles regarding implementation are explained in detail in Articles 164 to 172 of the relevant regulation. The behaviors that require disciplinary punishment are described in detail in a very wide range such as making the school and surrounding dirty or membership to illegal organizations. In the determination and implementation of the punishment for the students who are referred to the disciplinary committee due to these behaviors, the issues stated in the Article 168 of the related regulation are respected. It is seen that each case is evaluated in its own context and it is aimed to make the most accurate decisions possible. Finally, in the 169th article of the same regulation, issues related to the approval of punishments are included (MoNE, 2013). It can be understood from here that the punishments are examined by different authorities according to their degree before the application, and only after they are approved, they are applied.

Discipline, which is important in every stage of the education process, has a special importance for high schools. What makes this schooling level important is that the students are in adolescence period. Adolescence is an important developmental period between the ages of 12 and 18, in which 
many fundamental changes occur both physically and psychologically (Cüceloğlu, 2008; Moretti \& Peled, 2004). In this process, a student may experience conflicts in interaction with his / her environment. As a result, student misbehaviors may arise, and they may lead to discipline problems at school (Erdem, 2019). In the emergence of discipline problems, one should not think only in a student-oriented way. For example, Cemaloğlu $(2007$, p.12) lists the causes of discipline problems as "communication between the administrators, teachers and parents not being formed properly, the rules not being explained adequately to the students, their reasons not being expressed sufficiently, the rules being imposed on the students, and lack of applications and resources in the school". In this context, it can be said that variables such as the school climate, the values that the family transfers to the child, the models the society creates on the student and the quality of school guidance services are effective in the formation of disciplinary problems (Sarpkaya, 2007).

Considering the problems caused by student misbehaviors and the resulting discipline problems, it can be said that they reduce the effectiveness of education and negatively affect the school atmosphere, students' success and socialization. They also endanger school and student security (Akpınar \& Özdaş, 2013b; Kızmaz, 2004; Memduhoğlu \& Taşdan, 2007; Sezgin \& Duran, 2010). For this reason, to better understand the disciplinary issues at school becomes more important. As a result, examining the decisions taken in the disciplinary boards registered as the results of disciplinary practices in schools to reveal the disciplinary problems and reasons in high schools constitutes the main problem of the research.

\subsection{Purpose of the Research}

This research aims to reveal the discipline problems experienced in high schools and to provide an updated perspective for the possible solutions of the problems by examining the records of disciplinary committee minute books of high schools where the decisions taken in disciplinary committees are recorded and putting forth the reasons why high school students are punished and which punishments are given. The distribution of these punishments in terms of students' grade, school type and gender is also explored in the study. For these purposes, answers to the following questions are sought.

1- What is the distribution of disciplinary actions committed by the students?

2- What is the distribution of reasons for punishments in terms of gender according to disciplinary committee decisions?

3- What is the distribution of reasons for punishments in terms of grade level according to disciplinary committee decisions?

4- What is the total number of punishments in schools according to the disciplinary regulation?

5- What are the total numbers of students who were punished and not punished after discussion in disciplinary committee according to the disciplinary regulation?

6- What is the ratio of students who got punishment to total number of students according to the disciplinary regulation?

\section{Method}

This study, which is carried out to examine the decisions taken in the disciplinary committees, is a qualitative one. Qualitative research is carried out in its natural environment of the event or subject under investigation and expresses an inductive analysis process by the researcher, by means of methods specific to qualitative research (Yıldırım \& Simsek, 2018). In this study, qualitative research was preferred in order to analyze the information collected systematically and to reach a conclusion. The study is designed as a case study. A case study is an in-depth exploration of a bounded system (e.g. activity, event, process, or individuals), which means that the case is separated out for research in terms of time, place, or some physical boundaries (Creswell, 2012) and in this study, the decisions between the years 2016-2019 of the disciplinary 
committees of high schools in a district of a city in the Aegean region of Turkey are analyzed accordingly.

\subsection{Study Group}

The study group of the study consists of nine high schools located in a district of a province in the Aegean region of Turkey. Since the study was aimed at reaching all nine of the secondary education institutions in the district, no sample selection was made. In the study, there is an Anatolian High School (11.1\%), a Science High School (11.1\%), two Imam Hatip High Schools $(22.2 \%)$ and five Vocational and Technical High Schools (55.6\%). Table 1 shows the distribution of the students according to school type, gender and grade levels.

Table 1

Distribution of the students according to school type, gender and grade levels

\begin{tabular}{|c|c|c|c|c|c|c|c|c|c|c|c|c|}
\hline \multirow{2}{*}{ School Type } & \multicolumn{2}{|c|}{ Female } & \multicolumn{2}{|c|}{ Male } & \multicolumn{2}{|c|}{ 9th grade } & \multicolumn{2}{|c|}{ 10th grade } & \multicolumn{2}{|c|}{ 11th grade } & \multicolumn{2}{|c|}{ 12th grade } \\
\hline & $\mathrm{f}$ & $\%$ & $\mathrm{f}$ & $\%$ & $\mathrm{f}$ & $\%$ & $\mathrm{f}$ & $\%$ & $\mathrm{f}$ & $\%$ & $\mathrm{f}$ & $\%$ \\
\hline $\begin{array}{l}\text { Anatolian High } \\
\text { Schools (1) }\end{array}$ & 306 & 51.4 & 289 & 48.6 & 139 & 23.4 & 151 & 25.4 & 147 & 24.7 & 158 & 26.6 \\
\hline $\begin{array}{l}\text { Science High } \\
\text { School (1) }\end{array}$ & 201 & 52.8 & 180 & 47.2 & 89 & 23.4 & 97 & 25.5 & 94 & 24.7 & 101 & 26.6 \\
\hline $\begin{array}{l}\text { Imam Hatip } \\
\text { High Schools (2) }\end{array}$ & 335 & 65.9 & 173 & 34.1 & 117 & 23.0 & 124 & 24.4 & 135 & 26.6 & 132 & 26.0 \\
\hline $\begin{array}{l}\text { Vocational and } \\
\text { Technical High } \\
\text { Schools (5) }\end{array}$ & 430 & 40.3 & 636 & 59.7 & 282 & 26.5 & 270 & 25.3 & 261 & 24.5 & 253 & 23.7 \\
\hline
\end{tabular}

\subsection{Data Collection}

The method of data collection in the research is document analysis. Document analysis involves scanning documents for a specific purpose, finding resources, reading, taking notes, creating integrity from the acquired information and evaluating the information (Y1ldırım \& Şimsek, 2018). In order to carry out the study for the purpose of the research in secondary education institutions in the district, permission was obtained from the district governorate with the decision dated 28.02.2020 and numbered 11169268-44-E.4423847. Before starting the data collection, the school administrators were informed about the purpose of the research and information was obtained from the school administrators about the most appropriate days and times. Data collection was initiated by eliciting the list of students from the discipline board registers with the vice principal, who is the head of the discipline board in the school. At the same time, registers of the enforcement list of students who received disciplinary punishment was gathered from e-School system. Data were collected and categorized on a form prepared beforehand by the researchers. The form included categories of school type, disciplinary actions committed by students, gender, grade level, total number of punishment decisions and the numbers of students who were punished and not punished. It was filled in by the researchers by examining the data of the disciplinary committee minute books and "e-School" of the schools in the study group.

\subsection{Data Analysis}

The documents were analyzed and classified into categories using the form prepared beforehand by the researchers. Content analysis was performed on the data, frequency and percentile techniques were used, and the classified data were presented in tables and interpreted. To increase reliability the coding and the categories were cross checked by the authors. Besides, any researcher can reach the data from e-school system with proper permittance from the authorities and check the data. 


\section{Results}

The research findings are listed and interpreted in this part taking into account the research questions.

\subsection{Distribution of Disciplinary Actions Committed by the Students}

Table 2 gives information about the distribution of disciplinary actions committed by students.

Table 2

The distribution of disciplinary offenses committed by students

\begin{tabular}{lcc}
\hline Reason of the Punishment & \multicolumn{2}{c}{ Total } \\
& f & \% \\
\hline Fighting & 86 & 22.4 \\
\hline Possessing or smoking tobacco products & 58 & 15.1 \\
\hline Disrupting the course flow & 44 & 11.5 \\
\hline Behaving rudely and disrespectfully** & 42 & 10.9 \\
\hline Molesting, insulting and slandering friends with words and behavior & 30 & 7.8 \\
\hline Cheating** & 24 & 6.3 \\
\hline Absenteeism without excuse & 23 & 5.6 \\
\hline Behaving inappropriately against national and moral values & 22 & 5.7 \\
\hline Not complying with the provisions of regulation of dress & 13 & 3.4 \\
\hline Information technology offenses**** & 8 & 2.1 \\
\hline Carrying tools for gambling & 8 & 2.1 \\
\hline Damaging school***** & 7 & 1.8 \\
\hline Taking and using others' belongings without permission & 6 & 1.7 \\
\hline Bringing and using wounding or killing tools in the educational environment & 5 & 1.3 \\
\hline Ruining the order in the dorm & 4 & 1.0 \\
\hline Using or keeping addictive substances & 4 & 1.0 \\
\hline Total & $\mathbf{3 8 4}$ & $\mathbf{1 0 0}$ \\
\hline
\end{tabular}

*Similar offenses are grouped.

** Behaving rudely and disrespectfully: To insult and be rude to school administrators, teachers, employees, friends and other people in educational settings.

${ }^{* * *}$ Cheating: Cheating individually or with other people

****Information technology offenses: Using the IT tools out of purpose, to damage education and training activities and individuals through information tools or social media.

*****Damaging school: Making the school, its belongings and surroundings dirty; to damage the movable or immovable property of the school; writing political, ideological or obscene purposeful texts, drawing pictures or symbols on the school building, add-ons and equipment, and the tools and materials of their friends.

According to Table 2, the most committed disciplinary offense in the schools where the research was conducted was "fighting" (22.4\%) while the least committed disciplinary offenses were "using or keeping addictive substances" and "ruining the order in the dorm" $(1 \%)$. In addition to these, offenses of "possessing or smoking tobacco products" (15.1\%), "disrupting the course flow" $(11.5 \%)$ and "behaving rudely and disrespectfully" $(10.9 \%)$ are among the most committed offenses. 


\subsection{Distribution of Reasons for Punishments in Terms of Gender According to Disciplinary Committee Decisions}

The distribution of reasons for punishments in terms of gender can be seen on Table 3 .

Table 3

The distribution of reasons for punishments in terms of gender

\begin{tabular}{|c|c|c|c|c|c|c|}
\hline \multirow{2}{*}{ Reason of the Punishment } & \multicolumn{2}{|c|}{ Male } & \multicolumn{2}{|c|}{ Female } & \multicolumn{2}{|c|}{ Total } \\
\hline & f & $\%$ & f & $\%$ & $\mathbf{f}$ & $\%$ \\
\hline Fighting & 55 & 64.0 & 31 & 36.0 & 86 & 100 \\
\hline Possessing or smoking tobacco products & 43 & 74.1 & 15 & 25.9 & 58 & 100 \\
\hline Disrupting the course flow & 28 & 63.6 & 16 & 36.4 & 44 & 100 \\
\hline Behaving rudely and disrespectfully & 23 & 54.8 & 19 & 45.2 & 42 & 100 \\
\hline $\begin{array}{l}\text { Molesting, insulting and slandering friends with } \\
\text { words and behavior }\end{array}$ & 20 & 66.7 & 10 & 33.3 & 30 & 100 \\
\hline Cheating & 14 & 58.3 & 10 & 41.7 & 24 & 100 \\
\hline Absenteeism without excuse & 13 & 56.6 & 10 & 43.4 & 23 & 100 \\
\hline $\begin{array}{l}\text { Behaving inappropriately against national and moral } \\
\text { values }\end{array}$ & 16 & 72.7 & 6 & 27.3 & 22 & 100 \\
\hline $\begin{array}{l}\text { Not complying with the provisions of regulation of } \\
\text { dress }\end{array}$ & 5 & 38.5 & 8 & 61.5 & 13 & 100 \\
\hline Information technology offenses & 6 & 75.0 & 2 & 25.0 & 8 & 100 \\
\hline Carrying tools for gambling & 8 & 100 & - & - & 8 & 100 \\
\hline Damaging school & 6 & 85.7 & 1 & 14.3 & 7 & 100 \\
\hline $\begin{array}{l}\text { Taking and using others' belongings without } \\
\text { permission }\end{array}$ & 5 & 83.3 & 1 & 16.7 & 6 & 100 \\
\hline $\begin{array}{l}\text { Bringing and using wounding or killing tools in the } \\
\text { educational environment }\end{array}$ & 5 & 100 & - & - & 5 & 100 \\
\hline Ruining the order in the dorm & - & - & 4 & 100 & 4 & 100 \\
\hline Using or keeping addictive substances & 3 & 75.0 & 1 & 25.0 & 4 & 100 \\
\hline Total & 250 & 65.1 & 134 & 34.9 & 384 & 100 \\
\hline
\end{tabular}

According to Table 3, it is seen that in the schools where the research is conducted, only male students committed the offenses of "bringing and using wounding or killing tools in the educational environment" and "carrying tools for gambling" while female students only committed the offense of "ruining the order in the dorm". The most common offense committed by female students compared to male students is "not complying with the provisions of regulation of dress" with a rate of $61.5 \%$, whereas the highest disciplinary offense committed by male students compared to female students is "damaging school" with $85.7 \%$. Besides, male students commit disciplinary offenses such as "taking and using others' belongings without permission" $(83.3 \%)$, "possessing or smoking tobacco products" (74.1\%), "information technology offenses" (75\%), which distinguish them from female students. Disciplinary offenses that both male and female students practice in common the most are "behaving rudely and disrespectfully" and "absenteeism without excuse."

3.3. Distribution of Reasons for Punishments in terms of Grade Level according to Disciplinary Committee Decisions

Table 4 gives the frequencies and percentages of reasons for punishments in terms of grade level. 
Table 4

The distribution of reasons for punishments in terms of grade level

\begin{tabular}{|c|c|c|c|c|c|c|c|c|c|c|}
\hline \multirow{2}{*}{ Reason of the Punishment } & \multicolumn{2}{|c|}{$9^{\text {th }}$ Grade } & \multicolumn{2}{|c|}{ 10"th Grade } & \multicolumn{2}{|c|}{$11^{\text {th }}$ Grade } & \multicolumn{2}{|c|}{ 12th Grade } & \multicolumn{2}{|c|}{ Total } \\
\hline & $\mathbf{f}$ & $\%$ & $\mathrm{f}$ & $\%$ & $\mathrm{f}$ & $\%$ & $\mathbf{f}$ & $\%$ & $f$ & $\%$ \\
\hline Fighting & 33 & 38.4 & 40 & 46.5 & 8 & 9.3 & 5 & 5.8 & 86 & 100 \\
\hline $\begin{array}{l}\text { Possessing or smoking } \\
\text { tobacco products }\end{array}$ & 20 & 34.5 & 18 & 31.0 & 19 & 32.8 & 1 & 1.7 & 58 & 100 \\
\hline Disrupting the course flow & 22 & 50.0 & 11 & 25.0 & 11 & 25.0 & - & - & 44 & 100 \\
\hline $\begin{array}{l}\text { Behaving rudely and } \\
\text { disrespectfully }\end{array}$ & 19 & 45.2 & 14 & 33.3 & 6 & 14.3 & 3 & 7.2 & 42 & 100 \\
\hline $\begin{array}{l}\text { Molesting. insulting and } \\
\text { slandering friends with } \\
\text { words and behavior }\end{array}$ & 17 & 56.7 & 8 & 26.7 & 3 & 10.0 & 2 & 6.6 & 30 & 100 \\
\hline Cheating & 9 & 37.5 & 10 & 41.7 & 5 & 20.8 & - & - & 24 & 100 \\
\hline Absenteeism without excuse & 10 & 43.4 & 10 & 43.4 & 3 & 13.0 & - & - & 23 & 100 \\
\hline $\begin{array}{l}\text { Behaving inappropriately } \\
\text { against national and moral } \\
\text { values }\end{array}$ & 10 & 45.5 & 8 & 36.4 & 4 & 18.1 & - & - & 22 & 100 \\
\hline $\begin{array}{l}\text { Not complying with the } \\
\text { provisions of regulation of } \\
\text { dress }\end{array}$ & 5 & 38.5 & 2 & 15.4 & 6 & 46.1 & - & - & 13 & 100 \\
\hline $\begin{array}{l}\text { Information technology } \\
\text { offenses }\end{array}$ & 3 & 37.5 & 3 & 37.5 & 2 & 25.0 & - & - & 8 & 100 \\
\hline Carrying tools for gambling & - & - & 8 & 100 & - & - & - & - & 8 & 100 \\
\hline Damaging school & 2 & 28.6 & 5 & 71.4 & - & - & - & - & 7 & 100 \\
\hline $\begin{array}{l}\text { Taking and using others' } \\
\text { belongings without } \\
\text { permission }\end{array}$ & 3 & 50.0 & 2 & 33.3 & 1 & 16.7 & - & - & 6 & 100 \\
\hline $\begin{array}{l}\text { Bringing and using wounding } \\
\text { or killing tools in the } \\
\text { educational environment }\end{array}$ & 2 & 40.0 & 2 & 40.0 & 1 & 20.0 & - & - & 5 & 100 \\
\hline Ruining the order in the dorm & 1 & 25.0 & 2 & 50.0 & 1 & 25.0 & - & - & 4 & 100 \\
\hline $\begin{array}{l}\text { Using or keeping addictive } \\
\text { substances }\end{array}$ & 2 & 50.0 & 1 & 25.0 & - & - & 1 & 25.0 & 4 & 100 \\
\hline Total & 158 & 41.1 & 144 & 37.5 & 70 & 18.2 & 12 & 3.1 & 384 & 100 \\
\hline
\end{tabular}

According to Table 4, the most frequent disciplinary offense committed in schools is "fighting" $(n=86)$. It is understood from this table that $38.4 \%$ of $9^{\text {th }}$ grade students, $46.5 \%$ of $10^{\text {th }}$ grade students and $20.8 \%$ of $11^{\text {th }}$ grade students committed this disciplinary offense. In addition, although the offense of "carrying tools for gambling" was committed only by $10^{\text {th }}$ grade students, they committed the offense of "damaging school" (71.4) the most frequently. The most frequent offence committed by $9^{\text {th }}$ grade students is "molesting, insulting and slandering friends with words and behavior" (56.7\%), the one by $11^{\text {th }}$ grade students is "not complying with the provisions of regulation of dress" $(46.1 \%)$, the one by $12^{\text {th }}$ grade students is "using or keeping addictive substances" $(25 \%)$. As it can be inferred from the table the frequency and the percentages of the offenses decrease as the grade level increases. $9^{\text {th }}$ graders commit the most offenses $(f=158)$ while the $12^{\text {th }}$ graders commit the least. This finding may be about the process of getting used to a new environment and forming new relations with new people or maybe maturing in age. The national university entrance exam after graduation may also be a factor as it requires a special preparation. 
As the exam time gets closer, the students may realize that they need to study harder or listen better at school.

\subsection{Total Number of Punishments in Schools in accordance with MoNE Disciplinary Regulation}

The total number of punishments in schools according to the disciplinary regulation is presented at Table 5 .

Table 5

The total number of punishments in schools according to disciplinary regulation

\begin{tabular}{|c|c|c|c|c|c|c|}
\hline & \multicolumn{2}{|c|}{ 2019-2020 } & \multicolumn{2}{|c|}{ 2016-2019 } & \multicolumn{2}{|c|}{ TOTAL } \\
\hline & f & $\%$ & f & $\%$ & f & $\%$ \\
\hline Condemnation & 39 & 10.1 & 194 & 50.5 & 233 & 60.6 \\
\hline $\begin{array}{l}\text { Short-term } \\
\text { suspension from } \\
\text { school }\end{array}$ & 31 & 8 & 119 & 31 & 150 & 39 \\
\hline Change of school, & - & - & 1 & 0.2 & 1 & 0.2 \\
\hline $\begin{array}{l}\text { Exclusion from } \\
\text { formal education }\end{array}$ & - & - & - & - & - & - \\
\hline & & & & & 384 & 100 \\
\hline
\end{tabular}

As is evident in Table 5, the total number of sentences in the schools in the study group is 384 . $233(60.6 \%)$ of the total punishments is condemnation, $150(39 \%)$ are short-term suspension from school and $1(0.2 \%)$ is the punishment of changing school. According to the disciplinary regulations, no student has been sentenced to exclusion from formal education. The reason for opening two columns in Table 5 for the years of 2019-2020 and 2016-2019 is because the disciplinary punishments for the 2019-2020 academic year were not finalized yet.

3.5. Total Numbers of Students who were Punished and not Punished after Discussion in Disciplinary Committees according to Disciplinary Regulation

Table 6 gives information about the total numbers of students who were punished and not punished according to the disciplinary regulation after a final discussion in disciplinary committees.

Table 6

The total numbers of students who were punished and not punished after discussion in disciplinary committees (finalized)

\begin{tabular}{lcccccc}
\hline & \multicolumn{2}{c}{ Punished } & \multicolumn{2}{c}{ Not Punished } & \multicolumn{2}{c}{ Total } \\
& f & \% & f & \% & f & \% \\
\hline Female & 76 & 70,4 & 32 & 29,6 & 108 & 100 \\
\hline Male & 177 & 85,9 & 29 & 14,0 & 206 & 100 \\
\hline Total & 253 & 80,6 & 61 & 19,4 & 314 & 100 \\
\hline
\end{tabular}

As given in Table 5, 80.7\% of the total 314 disciplinary punishments, which were finalized, were recorded in the student file, while $19.4 \%$ were removed from the student file. $76(24.2 \%)$ of the students who got disciplinary punishment are girls and $177(56.4 \%)$ are boys. $32(10.2 \%)$ of the students who were discussed in the disciplinary committee but did not receive punishment were girls and 29 (9.2\%) were boys. Accordingly, the penalties received by male students were added to the student file in line with the regulations in a greater extent, while the punishments received by female students were removed from the student file more. According to the regulation, the criteria for removing disciplinary punishments from the student file include the quality and the importance of the behavior and under what conditions it was performed, the psychological 
condition of the student at the time of the conduct, the age and gender of the student, the student's interest and success in the lessons, whether the student had committed the same act before (MoNE, 2013).

\subsection{The Ratio of Students who got Punishment to Total Number of Students according to MoNE Disciplinary Regulation}

The numbers and the ratio of students who got punishment to total number of students according to MoNE disciplinary regulation is presented in Table 7. The numbers include both the ones that are recorded in the student files (finalized) and the ones that are not recorded yet (not finalized).

Table 7

The ratio of students who got punishment (both finalized and not finalized) to total number of students

\begin{tabular}{lccc}
\hline & $\begin{array}{c}\text { Total number of } \\
\text { students (1) }\end{array}$ & $\begin{array}{c}\text { Number of punished } \\
\text { students (2) }\end{array}$ & $\begin{array}{c}\text { Ratio of punished } \\
\text { students (2/1*100) }\end{array}$ \\
\hline $\begin{array}{l}\text { Vocational and Technical } \\
\text { High School }\end{array}$ & 1066 & 259 & 24.3 \\
\hline Imam-Hatip High School & 508 & 16 & 3.1 \\
\hline Anatolian & 595 & 100 & 16.8 \\
\hline Science & 381 & 9 & 2.3 \\
\hline Total & 2550 & 384 & 15.0 \\
\hline
\end{tabular}

When Table 7 is analyzed, it is understood that $15 \%$ of students in high schools located in the district were involved in disciplinary events and received punishment which is a high ratio. Considering that there are 30-40 students in the classes, it can be said that an average of 4-5 students are punished in each class. When the ratio of students who got punishment to total students is analyzed, it is seen that Vocational and Technical High School students (24.2\%) received the highest number of punishments while Science High School students (2.3\%) received the least.

\section{Discussion and Conclusion}

Based on the disciplinary offenses of students attending to nine secondary education schools located in a district of a city in the Aegean region of Turkey, this case study examines the disciplinary offenses of students, distribution of these offences in terms of gender and grade level, the total number of students, the ratio of punishments to total school population, and the finalized punishments given in the board meetings at the end of the academic year through document analysis method.

According to the results of the research, when the distribution of disciplinary punishments is examined in terms of gender variable, it is seen that male students receive more disciplinary punishments than female students. Some studies in the literature support this finding. For example, in the studies by Akpınar and Özdaş (2013a; 2013b) in Diyarbakır province, Koç (2006), Arslan et al. (2010) in Ankara province, and Güçlü (2004) in high schools in Kayseri province, it was found that male students committed more offenses than female students and they show more aggressiveness. In line with the results, it is observed that male students are distinguished from female students in that they commit offenses such as "bringing and using wounding or killing tools in the educational environment, taking and using others' belongings without permission, possessing or smoking tobacco products, information technology offenses and fighting" more frequently. Akpınar and Özdaş (2013b) stated that mainly male students committed offenses such as smoking, copying, disobeying to school rules, keeping wounding gears and organizational offenses. Uzbaş and Kabasakal (2010) found out that male students had a fight rate of two and a half times higher than female students. In this study, female students came to the fore with crimes such as "ruining the order in the dorm and not complying with the provisions of regulation of dress". When the results of the research are evaluated in this context, it can be said that male 
students show behaviors based on power and violence, and female students differ in this regard. Among the reasons for this result may be the cultural judgments that bring the society together, academic success or hopes and responsibilities for the future (employment, financial concerns etc.), as well as the physiological characteristics of male students at adolescence ages.

According to the results of the research, when the distribution of disciplinary offenses in terms of grade level is examined, it is seen that the discipline punishment is the highest for the 9th grade and the minimum for the 12th grade. In the study conducted by Güçlü (2004), the number of discipline punishment was the highest among the 11th grades, and in the study carried out by Akpınar and Özdaş (2013a), the rate of discipline punishment in schools was the highest in the 9th grades. Among the reasons for 9th grade students being punished at a high rate may be related to reasons such as coming to a different environment, to a new school type, not being able to adapt to new school rules, and attempting to exhibit the same attitudes in high school that were actually problematic but mostly ignored in elementary and lower secondary schools due to their age (Akpınar \& Özdaş 2013a). Besides maturing with age and the nation-wide university entrance exam after the graduation may be factors for decreasing levels of disciplinary punishments for the higher grade levels. As the exam time gets closer, the students may realize that they need to study harder or listen better at school. In addition, just a process of getting used to the new environment (a new school level or type here) may also be a factor for this. According to Valdebenito et al., and (2019) Obsuth et al. (2016) a positive relationship between teachers and students is also an important factor for students to promote more prosocial and less aggressive behaviors both at school and in later life. Therefore, as knowing each other and setting up relationships take time, the students and teachers would know each other better and would have chances of setting up sound relationships in time. Thus, a higher grade level means more time and better chances to set up relationships both for teachers and the students. This point may also be the reason behind the decrease of disciplinary problems as the grade level increases.

According to the research, although the highest number of disciplinary punishment was seen in the 9th grades, the second most frequent disciplinary punishment after the condemnation, which is short-term suspension from school, was received by the students at the 10th grade at most. These students' age and grade level and also an expectation from them to exert constructive and positive behaviors as their level of adaptation to the setting increase may be among the reasons of this case. As a result of this expectation, they may be punished more strictly relative to other grade levels. That the number of offences in $12^{\text {th }}$ grade being not very high can be considered as positive as they may be affected psychologically due to concerns for future and exams as well as the uncertainty of passing to a higher education level or job life. In addition, when the behaviors that are shown as a reason for discipline punishments are examined with respect to grade levels, it is revealed that the $9^{\text {th }}$ grade students committed the offense of "molesting, insulting and slander friends with words and behavior" most, the $10^{\text {th }}$ grade students committed the offense of "giving damage to schools" most, $11^{\text {th }}$ grade students committed the offense of "not complying with the provisions of regulation of dress" most, and $12^{\text {th }}$ grade students committed the offense of "using or keeping addictive substances" most. According to Akpınar and Özdaş (2013a) among the most frequent offences committed by high school students disrupting the flow of the courses or the exams, smoking or carrying cigarette packages and being disrespectful to the teacher. In his research, Kök (2007) stated that the most common problems seen in high schools are insulting, molesting, fighting and slander. Aydın (2011) listed problems with friends and courses, absenteeism, not obeying to rules, and problems related to dressing. Akar (2006) argued that offences such disrupting the lesson, fighting at school, smoking, keeping wounding tools, and disrespect for the teacher were committed in schools.

According to the results of the research, the most frequent disciplinary punishment received in the schools where the study is conducted is condemnation with a rate of $60.6 \%$. It is seen that no student received the punishment of exclusion from formal education, which is one of the most severe punishments according to the discipline regulation, and only one student received the 
punishment of changing schools. In the studies by Akpınar and Özdaş (2013a; 2013b) and Şenuyar (1989), the most frequent punishment is "short-term suspension from school", while it is "Warning-Deprivation-Condemnation" in Kabaday1 and Güneş's (2001) study, and "condemnation" in the studies by Toytok and Yildırım (2018) and Mercan (2001). Differences in the names of disciplinary punishments result from changes made in the regulations over the years. With this study, although the findings of the above-mentioned studies are parallel, it is understood that the students completed the academic year with mild punishments in general. Among the reasons for this case may be the basic principles of contemporary education approaches. Because, according to the contemporary understanding of education, the purpose of discipline in schools is not to punish students, to exclude them from the educational phase or to be authoritarian. On the contrary, the discipline in schools can be ensured in ways such as being a model for the student, implementing corrective, preventive and effective teaching methods and healthy communication with the students (Adams \& Hamm, 1994, as cited in Kabaday1 \& Güneş, 2001). Besides, in the related literature there are studies discussing the negative aspects of the exclusion from schools and/or the ways to reduce it and its negative effects by finding ways solving disciplinary problems without exclusion (Obsuth et al. 2016; Valdebenito et al., 2019).

It is also revealed in the study that when the status of the disciplinary punishments determined by discussions in the disciplinary committees is taken into consideration, it is seen that the disciplinary punishments received by male students are added more to the student file, while the disciplinary punishments received by female students are added to the student file to a lesser extent. In the $168^{\text {th }}$ article of the regulation, the issues to be considered for approval of punishments include the quality and the importance of the behavior and under what conditions it was performed, the psychological condition of the student at the time of the conduct, the age and gender of the student, the student's interest and success in the lessons, whether the student had committed the same act before (MoNE, 2013). In this study, the reasons such as female students' not repeating the same offenses, their success in lessons or gender factor can be shown among the reasons for disciplinary punishment being removed more than male students. On the other hand, disciplinary punishment may have been removed for female students in order not to tend to false perceptions because a female student who is punished due to the structure of the society may be welcomed with less tolerance due to traditional judgments (Kabadayı \& Güneş, 2001). Particularly considering that there is an effort to direct girls to school and education (campaigns aiming to increase girls' schooling) in Turkey, this kind of tendency may have occurred for the purpose of preventing girls from leaving education. The question that should be asked here is that is there such an attitude also for male students? Did the current situation arise despite such a positive attitude? This is an issue to be considered.

The results suggest that when the ratio of students who got punishment to total students and the distribution of disciplinary punishment in terms of school type are analyzed, it is seen that Vocational and Technical High School students received the highest number of punishments while Science High School students received the least. Kabadayı and Güneş (2001) identified that the highest number of punishments was given to students at Girls' Vocational Technical High Schools and the least number of punishments was given to students at Private, Anatolian and Science High Schools. The findings of this study are in parallel with the current study. The reason for the higher number of penalties in vocational and technical high schools in the study is that the majority of the schools in the study group are vocational high schools. The difference in the perspectives of school administrators, disciplinary committees, or students' expectations of these schools from school or life may be some reasons for this. In the study by Tunç, Yıldız and Doğan (2015), discipline problems were experienced in vocational high schools due to the reasons such as prevalence of bad examples on TV and internet, students' developmental characteristics, family problems, lack of future anxiety of the student, insufficient disciplinary regulations and excessive hours of lessons and therefore, it was stated that disciplinary punishments were high in this type of school. There are also studies considering television or computer games as a possible source of violence-based 
discipline problems (Yörük, Koçyiğit, \& Turan, 2015). In addition, it is noteworthy that disciplinary offence is less common in schools that accept students through examination, but it is important to work to increase the academic success level and expectation in vocational high schools, to change the perception towards the relevant schools positively and to increase their importance in the education system.

An evaluation of the results in the current study suggests that teachers at secondary education institutions should be enlightened through in-service seminars about the characteristics of students at this developmental period because some of the discipline problems in high schools actually arise due to the problems peculiar to adolescence period. In addition to increasing the academic success in schools, cultural sports activities can also be a source of solution in reducing discipline problems. Cooperation with health institutions should be established on the use of smoking or addictive substances in schools. It is important to invest effort to change the perception towards vocational high schools in a positive way by reconsidering the situation of the schools where disciplinary problems are experienced most. This research was carried out only considering the data of "Disciplinary Committee Minute Book" and "e-School". The discipline issue in schools can be examined in more detail in order to reveal the reasons underlying students' behaviors that cause disciplinary problems, where students' defenses can be examined and opinions of members of the disciplinary committee can be obtained.

\section{References}

Ada, S. \& Çetin-Ölçüm, M. (2006). Eğitim ve öğretim ortaminda disiplin nedir? [What is discipline in education and training environment?]. Ankara: Nobel.

Akar, N. (2006). The disciplinary problems faced in high schools and problem solving attitudes of administrators (Denizli Example) (Unpublished Master's Thesis). Pamukkale University, Institute of Social Sciences, Denizli.

Akpınar, B. \& Özdaş, F. (2013a). Investigation the high school discipline problems in terms of gender variable. Dicle University Journal of Ziya Gökalp Education Faculty, 21, 20-29.

Akpınar, B. \& Özdaş, F. (2013b). An analysis of discipline problems in high school from the variable of grades. Kastamonu Education Journal, 21(4), 1365-1376.

Amoah, S. A., Owusu-Mensah, F., Laryea, P. \& Gyamera, A. (2015). Managing school discipline: The students' and teachers' perception on disciplinary strategies. British Journal of Psychology Research, 3(2), 111.

Arslan, C., Hamarta, E., Arslan, E. \& Saygin, Y. (2010). Investigation of aggression and interpersonal problem solving in adolescents. Elementary Education Online, 9(1), 379-388,

Aydin B. (2011). Solution offers of guidance counselor for unfavorable behaviors of student. e-Journal of New World Sciences Academy Education Sciences, 6(4), 2469-2481.

Babaoğlan, E. (2014). Sinıfta disiplin ve disiplin modelleri [Discipline in class and discipline models]. In M. Çelikten and M. Teyfur (Eds.), Yapılandırmacı yaklaşıma göre sinıf yönetimi [Classroom management according to constructivist approach] (pp.47-74). Ankara: Anı.

Başaran, İ. \& Çınkır, Ş. (2013). Türk eğitim sistemi ve okul yönetimi [Turkish education system and school management] (4th Edition). Ankara: Siyasal.

Baumann, C. \& Krskova, H. (2016). School discipline, school uniforms and academic performance. International Journal of Educational Management, 30(6), 1003-1029.

Buchtova, T., Kucerova, L., Chudy, S. \& Neumeister, P. (2015). The concept of discipline in novice teachers in primary schools. International Journal of Educational Science and Research, 5(1), 39-48.

Camacho, K. A. \& Krezmien, M. P. (2020). A statewide analysis of school discipline policies and suspension practices. Preventing School Failure: Alternative Education for Children and Youth, 64(1), 55-66. https://doi.org/10.1080/1045988X.2019.1678010

Celep, C. (2008). Sinif yönetiminde kuram ve uygulama [Theory and practice in classroom management] (3rd Edition). Ankara: Pegem.

Cemaloğlu, N. (2007). Concepts, principles and practices related to discipline. Journal of National Education, $175,8-23$.

Cemaloğlu, N. \& Kayabaşı, Y. (2007). The relationship between the burnout level of teachers classroom management and discipline models. Journal of Gazi Education Faculty, 27(2), 123-155. 
Creswell, J. W. (2012). Educational research: planning, conducting, and evaluating quantitative and qualitative research (4th ed.). Pearson: The USA.

Cüceloğlu, D. (2008). İnsan ve davranışı [Human and behavior] (17th ed). İstanbul: Remzi.

Cüceloğlu, D. (2016). İ̧̧imizdeki çocuk [The child inside] (50th ed.). İstanbul: Remzi.

Çelik, S. (2006). Disiplin ile sınıfta kural ve işlemlerin belirlenmesi ve uygulanması [Determination and implementation of rules and procedures in class with discipline]. In M. Yalçınkaya and İ. Günbayı (Eds.), Sinif yönetimi [Classroom management] (pp. 51-89). İstanbul: Lisans.

Durukan, H. \& Öztürk, H. İ. (2005). Sinıf yönetimi [Classroom management]. İstanbul: Lisans.

Ercan, L. (2007). Sınıfta istenmeyen davranışların yönetimi [Management of student misbehvaiors in class]. In L. Küçükahmet (Ed.). Sinıf yönetimi [Classroom management] (pp. 193-220). Ankara: Pegem Akademi.

Erdem, A. R. (2015). Sinıf disiplini ve kuralları [Classroom discipline and rules]. In R. Sarpkaya (Ed.), Sinıf yönetimi [Classroom management] (pp. 81-116). Ankara: Anı.

Erdem, C. (2019). Öğrenci davranışlarının yönetimi [Managing student behaviors]. In M. Koçyiğit (Ed.). Sinıf yönetimi [Classroom management] (pp.79-103). Konya: Eğitim.

Güçlü, M. (2004). An evaluation process of secondary level students who were given a discipline penalty in term of their socio-economic level (Kayseri example) (Unpublished Master's Thesis). Erciyes University, Institute of Social Sciences, Kayseri.

İlgar, L. (2000). Eğitim yönetimi okul yönetimi smnf yönetimi [Education management school management classroom management]. İstanbul: Beta.

Kabaday1, R. \& Güneş, Y. (2001). Discipline in İzmir lycees. Education and Science, 26(119), 66-70.

Kaçar, T. (2018). Problems encountered in secondary education institutions. The Journal of International Social Research, 11(58), 524-534.

Karataş, Z. (2008). Lise Öğrencilerinin suçluluk ve utanç puanlarının disiplin cezası alıp almama ve cinsiyetleri açısından incelenmesi [Examination of high school students' guilt and shame scores in terms of whether they received disciplinary punishment and their gender]. Mersin University Journal of the Faculty of Education, 4(2), 103-114.

Kıran, H. (2005). Etkili sinff yönetimi [Effective classroom management]. Ankara: Anı.

Kizmaz, Z. (2004). Educational level and crime: A sociological research on the relation between school and crime. Firat University Journal of Social Sciences, 14(2), 291-319.

Koç, Z. (2006). Regresment of high school students`bullying level (Unpublished Doctoral Dissertation). Gazi University, Institute of Educational Sciences, Ankara.

Koçyiğit, M. (Ed.). (2019). Sınıf yönetimi [Classroom management]. Konya: Eğitim.

Kök, M. (2007). Views of the high school teachers, guidance counselors and directors related to the disruptive behaviors and punishments in secondary education awards and punishment regulations (Unpublished Doctoral Dissertation). Hacettepe University, Institute of Social Sciences, Ankara.

Köktaş, Ş. (2003). Sinıf yönetimi [Classroom management]. Adana: Nobel.

Lewis, R. (2001). Classroom discipline and student responsibility: The students' view. Teaching and Teacher Education, 17(1), 307-319.

Memduhoğlu H. B. \& Taşdan, M. (2007). School and student safety: A conceptual analysis. Journal of Çukurova University Faculty of Education, 3(34), 69-83.

Mercan, M. (2001). The investigations about results of discipline punishment in the high schools (Unpublished Master's Thesis). Çukurova University, Social Sciences Institute, Adana.

MoNE. (2013). Millî eğitim bakanlı̆̆ı ortaöğretim kurumları yönetmeliği [Ministry of national education secondary education institutions regulation]. Resmî Gazete [Official Gazette] (Say1/Number: 28758). https://ogm.meb.gov.tr/meb_iys_dosyalar/2019_07/16134512_yonetmelik.pdf

Moretti, M. M. \& Peled, M. (2004). Adolescent-parent attachment: Bonds that support healthy development. Paediatr Child Health, 9(8), 551-561.

Mowen, T. J., Brent, J. J. \& Boman IV, J. H. (2020). Effect of school discipline on offending across time. Justice Quarterly, 37(4), 739-760. https:// doi.org/10.1080/07418825.2019.1625428

Ngwokabuenui, P. Y. (2015). Students' indiscipline: types, causes and possible solutions: the case of secondary schools in Cameroon. Journal of Education and Practice, 6(22), 64-72.

Obsuth, I., Sutherland, A., Cope, A., Pilbeam, L., Murray, A. L. \& Eisner, M. (2016). London education and inclusion project (LEIP): Results from a cluster-randomized controlled trial of an intervention to reduce school exclusion and antisocial behavior. Journal of Youth $\mathcal{E}$ Adolescence, 46, 538-557. https://doi.org/10.1007/s10964-016-0468-4 
Oxford Learner's Dictionary. (n.d.). Oxford Learner's Dictionary. https://www.oxfordlearnersdictionaries.com

Sadık, F. (2006). Investigation of students' unwanted behaviors and strategies to cope with these behaviors according to teachers', students' and parents' opinions and the effect of the training program applied based on the confident discipline model on teachers' coping strategies (Unpublished Doctoral Dissertasstion). Çukurova University, Social Sciences Institute, Adana.

Sarıtaş, M. (2005). Sınıf yönetimi ve disiplinle ilgili kurallar geliştirme ve uygulama [Developing and implementing rules regarding classroom management and discipline]. In L. Küçükahmet (Ed.), Sinıf yönetiminde yeni yaklaşımlar [New approaches in classroom management] (pp. 43-85). Ankara: Nobel.

Sarpkaya, P. (2007) . The reasons of disciplinary problems at state high schools according to the opinons of administrators, students, teachers and family members. Pamukkale University Journal of Education, 22, 110121.

Sezgin, F. \& Duran, E. (2010). Prevention and intervention strategies of primary school teachers for the misbehaviors of students. Journal of Gazi Education Faculty, 30(1), 147-168.

Şenuyar, A. M. (1989). Penalty and award in Elazig secondary schools 1977-1988 (Unpublished Master's Thesis). Furat University, Institute of Social Sciences, Elazı $\breve{g}$.

Tertemiz, N. (2007). Sınıf yönetimi ve disiplin modelleri [Classroom management and discipline models]. In L. Küçükahmet (Ed.). Sinıf yönetimi [Classroom management] (pp. 110-131). Ankara. Pegem Akademi.

Tofur, S. \& Altıntaş, G. (2019). Sınıf yönetiminde disiplin ve disiplin modelleri [Discipline in classroom management and discipline models]. In M. Koçyiğit (Ed.). Sinıf yönetimi [Classroom management] (pp. 79103). Konya: Eğitim.

Toytok, E. H. \& Yildırım M. B. (2018). Disciplinary problems and causes of vocational high school. Journal of Abant Izzet Baysal University Faculty of Education, 18(3), 1759-1778.

Tunç, B., Yıldız, S. \& Doğan, A. (2015). Discipline problems in vocational high school causes and solutions: A case study. Journal of Abant Izzet Baysal University Faculty of Education, 15(2), 384-403.

Turkish Language Association. (2005). Türkce sözlük [Turkish Dictionary]. Ankara: TDK Yayınları.

Uğurlu, C. T. (2016). Disiplin ve sınıf yönetimi yaklaşımları [Discipline and classroom management approaches]. In C. T. Uğurlu (Ed.). Sinıf yönetimi [Classroom management] (pp.40-60). Ankara: Anı.

Uzbaş, A. \& Kabasakal, Z. (2010). The prevalence of aggressive and violent behaviors among elementary school students. Elementary Education Online, 9(1), 93-105.

Valdebenito, S., Eisner, M., Farrington, D. P., Ttofi, M. M. \& Sutherland, A. (2019). What can we do to reduce disciplinary school exclusion? A systematic review and meta analysis. Journal of Experimental Criminology, 15, 253-287. https:/ / doi.org/10.1007/s11292-018-09351-0

Yavuzer, H. (2016). Çocuk psikolojisi [Child Psychology]. İstanbul: Remzi.

Yıldırım, A. \& Şimşek, H. (2018). Sosyal bilimlerde nitel araştırma yöntemleri [Qualitative research methods in social sciences]. Ankara: Seçkin.

Yiğit B. (2006). Sınıfta disiplin ve öğrenci davranışlarının yönetimi [Discipline in the class and management of student misbehaviors]. In M. Şişman and S. Turan (Eds.), Sinıf yönetimi [Classroom management] (pp. 4358). Ankara: Pegem Akademi.

Yörük, S., Koçyiğit, M. \& Turan, M. (2015). The effect of tv series and computer games on the perceptions of violence of secondary school students. Journal of Social Sciences, 8(4), 127-142. 